\title{
Overview of Pronk's day gecko Phelsuma pronki (Seipp, 1994) (Reptilia Gekkonidae) from Mangabe protected area, eastern Madagascar
}

\author{
Raphali R. Andriantsimanarilafy', Pierre Razafindraibe', Emile Razanakoto' \& B. Razafimahatratra2* \\ ${ }^{1}$ Madagasikara Voakajy, BP 5181, Antananarivo, Madagascar \\ ${ }^{2}$ Mention Zoologie et Biodiversité Animale, Faculté des Sciences, Université d'Antananarivo, BP 906, Antananarivo, 101 Mada- \\ gascar \\ ${ }^{*}$ Corresponding author, email: arraphali@voakajy.mg
}

\begin{abstract}
We surveyed Pronk's day gecko Phelsuma pronki (Seipp, 1994) (Reptilia Gekkonidae) from three sites within Mangabe protected area. Sites were chosen according to their location and altitude. Fieldwork was done in October-November 2018 when the animal is very active. Thirty transect lines were surveyed, ten for each site. One transect measure $200 \mathrm{~m}$ and distance between transects should be $50 \mathrm{~m}$ at least to avoid pseudo-replication on transect location. In total, we encountered 31 individuals, 18 of them were found from Analamay forest. The species was found mostly on dead trees from an open area inside of primary forest.
\end{abstract}

KEY WORDS Conservation; Habitat; Mangabe; Phelsuma pronki; Population; size.

Received 05.03.2020; accepted 13.05.2020; published online 30.06.2020

\section{INTRODUCTION}

The genus Phelsuma Gray, 1825 (Reptilia Gekkonidae) is a group of day geckos with splendid colourations that is mainly distributed on the islands in the western Indian Ocean (Glaw \& Rosler, 2015). Madagascar is home of 35 species (Uetz \& Hošek, 2014) and some papers indicated that the genus Phelsuma probably originated in Madagascar and subsequently dispersed and radiated in the other Indian Ocean archipelagos, with a different colonisation history on each island group (Austin et al., 2004; Harmon et al., 2008; Rocha et al., 2009, 2010). The last red list assessment classified 12 species, and of these about 1/3 of Malagasy Phelsuma are threatened and four of them were listed Critically Endangered. Regardless of their IUCN Red List status all Phelsuma species are listed on the CITES Appendix II (Glaw \& Rosler, 2015).
Phelsuma pronki (Seipp, 1994) is endemic to Madagascar and occurs in isolated fragments in the eastern rainforest bordering the central highlands of Madagascar, in the Andramasina region, Anjozorobe reserve and in the Ambatovy area. It is one of the Critically Endangered species because of its extent of occurrence is estimated less than $100 \mathrm{~km}^{2}$. It only persists in severely fragmented forest habitat, which is still being degraded by human pressures such as habitat loss occurring within this species' range and harvesting for the international pet trade. Populations of this species have declined over the past years (Raxworthy \& Vences, 2010). Few individuals of the species were found from Mangabe protected area in 2014 (Bower et al., 2014). This study aims to collect more information on Pronk's day gecko within the protected area such as its distribution, population size and habitat preferences for the benefit of its conservation. 


\section{MATERIAL AND METHODS}

Field work was done within Mangabe-Ranomena-Sahasarotra reserve which is situated in southwestern of Moramanga between Latitude S $19^{\circ} 00$ and $\mathrm{S} 19^{\circ} 28$ and Longitude $\mathrm{E} 48^{\circ} 05$ and $\mathrm{E} 48^{\circ} 25$ with an altitude range between 800 to 1300 meters (Madagasikara Voakajy, 2015). It is included in the east at mid-altitude bioclimatic zone described by Du Puy \& Moat (1996). The vegetation is dominated by evergreen humid forest characterized by high canopy and closed forest. We selected three camp sites within the protected area which have been chosen according to their biogeography and the altitude range. The first camp was Ampahatra situated in the north of the protected area with low altitude range between $943-990 \mathrm{~m}$. The second camp was Lakambato in the middle with an altitude between 989 to 1039 meters. The last camp was Analamay situated so far in the south with an altitudinal range between 996 to 1089 meters (Fig. 1).

We surveyed Pronk's day gecko along 10 transects of $200 \mathrm{~m}$ from each camp site. Transects were installed in different types of habitat such as forest edge, interior of the forest following the top, and degraded area outside of the forest with dead trees. Each transect was visited three times: twice in the morning between $7 \mathrm{~h} 00$ to $11 \mathrm{~h} 30$ and once in the afternoon between $13 \mathrm{~h} 00$ to $15 \mathrm{~h} 00$; towards these hours, the geckos are more active and easier to find. The survey was done by four people composed of one specialist and three trained guides who knew the species and the area of interest. For each observation, we collected data on: animal height from the ground, total tree height, life status of the tree, activity of the animal at its first observation, GPS coordinates. We calculated the kilometric abundance index (KAI) following the formula adapted from Preatoni et al. (2012).

$$
\mathrm{KAI}=\frac{\text { Number of presence sightings }}{\text { Transect length covered }(\mathrm{m})} * 1 \mathrm{~km}
$$

\section{RESULTS AND DISCUSSIONS}

In total, we encountered 31 individuals with 25 observed along transects and 6 incindentally ob-

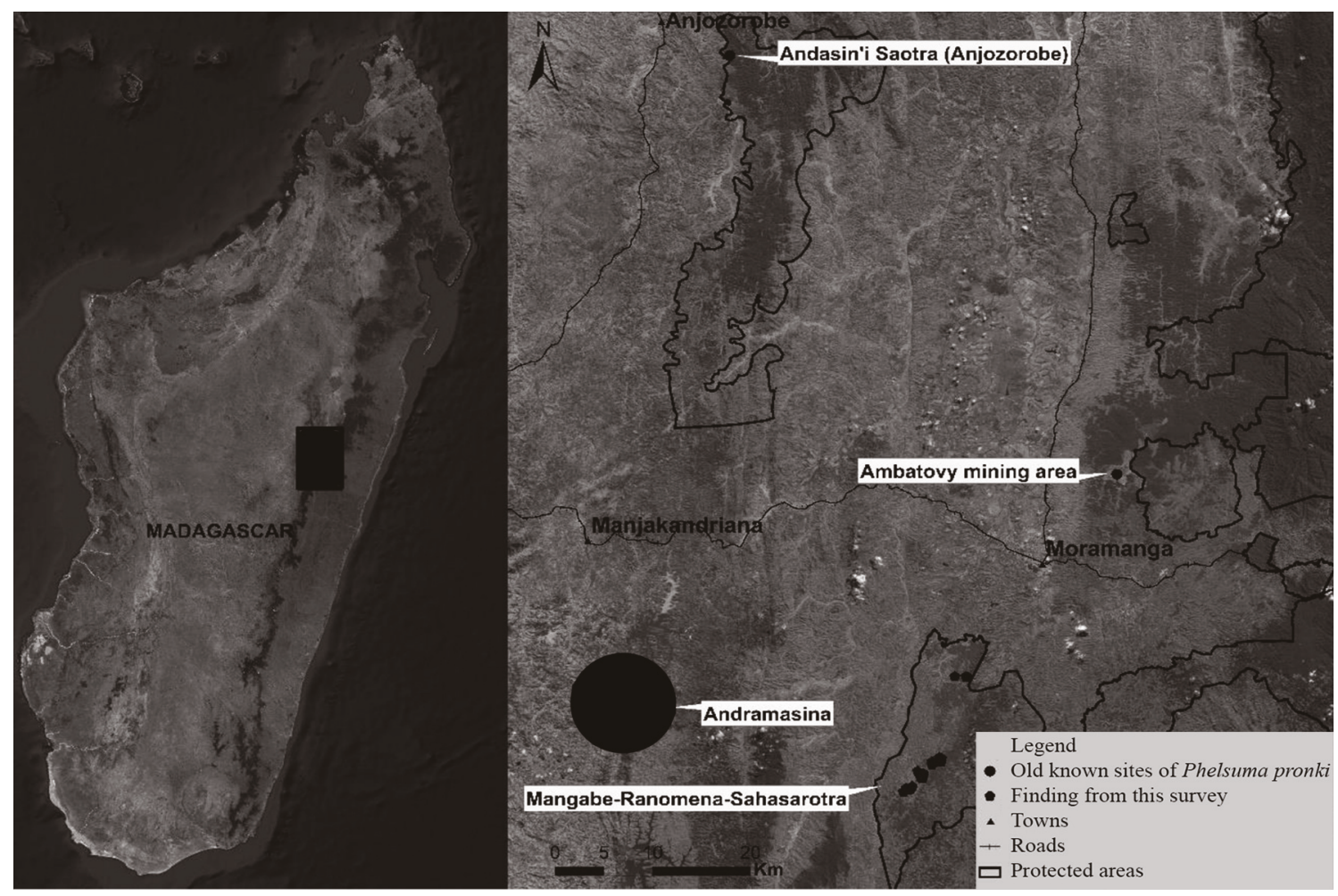

Figure 1. Map showing study sites and Pronk's day gecko distribution in Madagascar. 


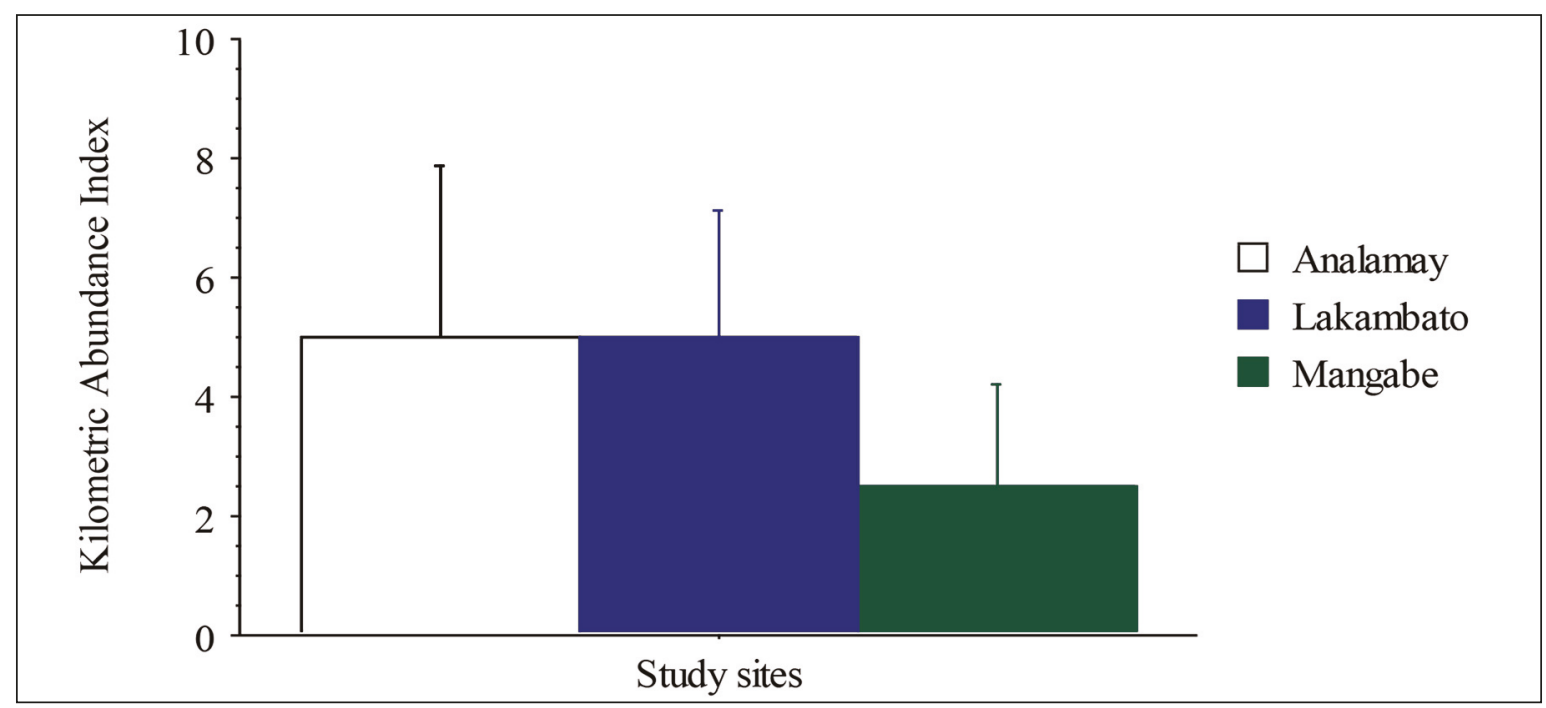

Figure 2. Kilometric abundance index (KAI) per site.

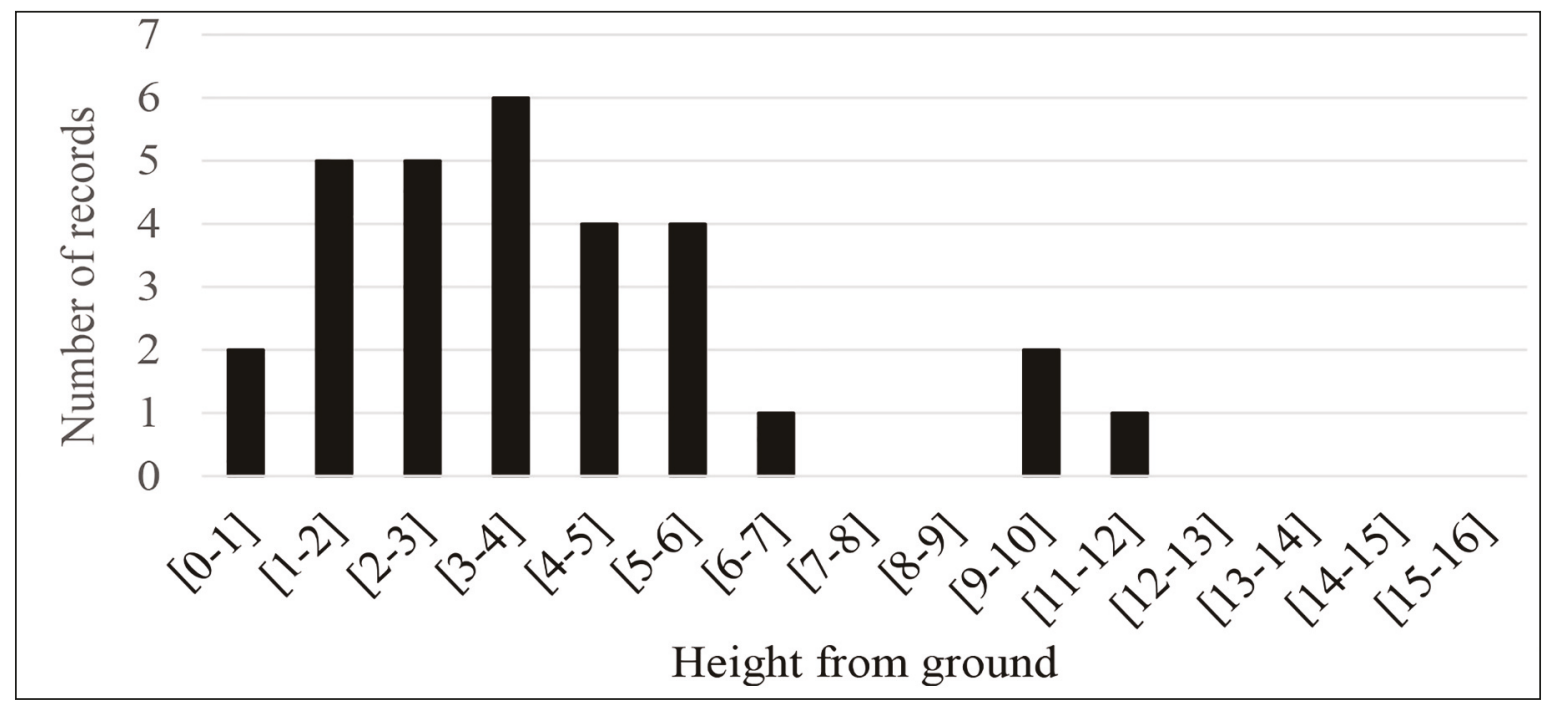

Figure 3. Frequency of roosting height.

served along the road. Abundance index changes between sites, as Analamay and Lakambato had the same abundance of 5 ind.km-1, in contrary to Ampahatra site with 2.5 ind.km-1 (Fig. 2). However, this difference is not significant ( $\mathrm{p}$-value $=0.53$ ). All the six incidental observations were found in Analamay forest. Twenty-eight of the individuals were adult and we found gravid female during the survey. Pronk's day gecko was found mostly in dead tree but we found two individuals on living trees one in Ankolokoloka forest in Lakambato site and the other one from Analamay. Most individuals were observed by themselves, with the exception of four cases in which two couples were found in one tree in Analamay and Lakambato. This study confirms the presence of Pronk's day gecko within Mangabe protected area situated about $30 \mathrm{~km}$ east of Andramasina and can be considered as a range extension in addition to its actual range during its conservation status assessment. This site is actually protected but threats still exist there which can affect the species such as slashand-burn agriculture and illegal collection. Despite 


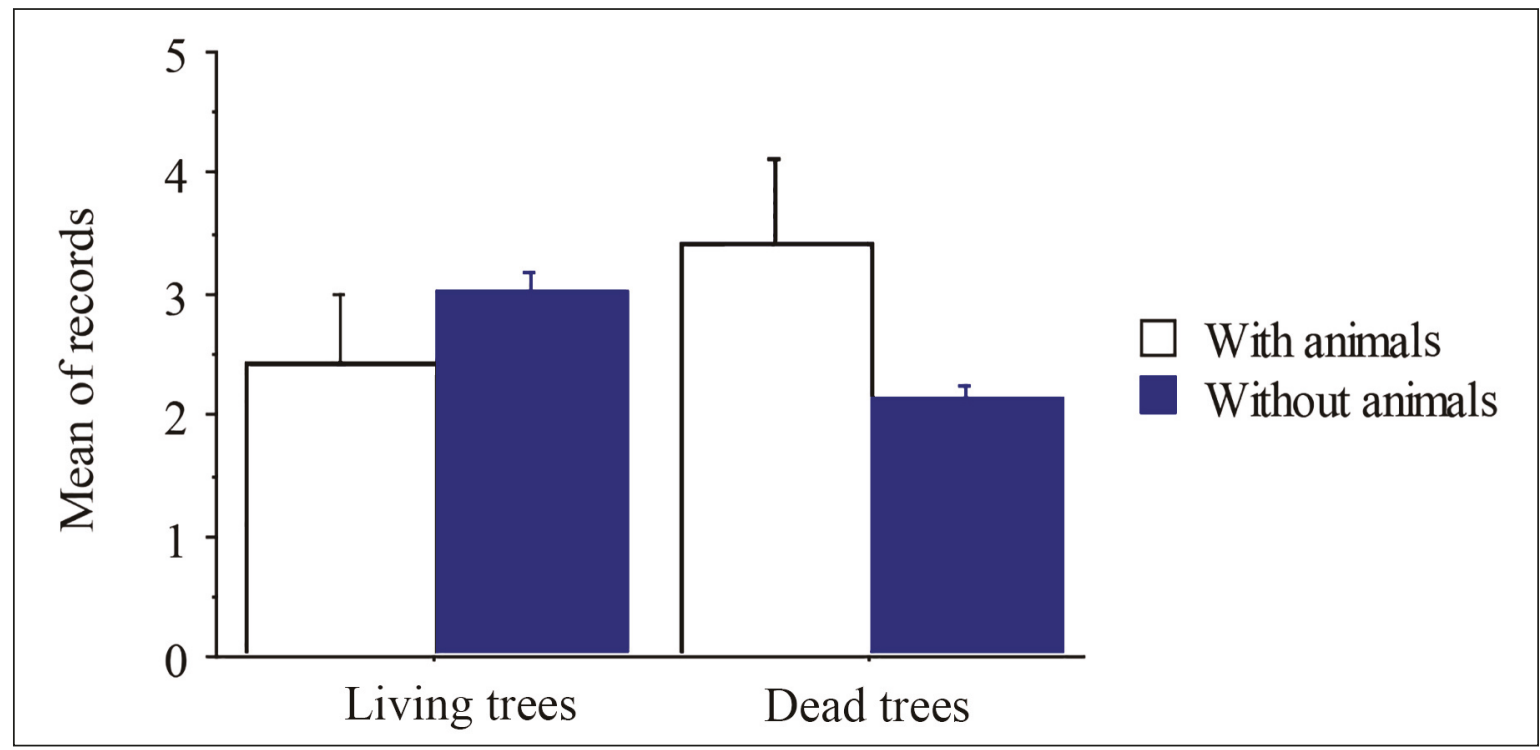

Figure 4. Number of dead and living trees from the areas with and without animals.

this range extension, the species still under threat can be considered as Critically Endangered according to A1 criteria (IUCN, 2001. A: population size reduction; 1: if the reasons for population reduction no longer occur and can be reserved, the population needs to have been reduced by al least $90 \%$ ).

The species was found from 0.5 to ten meters above ground, with 24 of them between one to six meters (Fig. 3). Phelsuma pronki prefers big dead trees easily exposed to the sun early in the morning and late in the afternoon. They were all found on the main trunk in the middle of the tree. At their first observation, only four individual were actively running or searching food.

During this survey, we found the animal from areas where dead trees were abundant but with less disturbance (Fig. 4). All individuals were observed on trees which confirm Seipp's statement that the species is arboreal and is known to be from humid rainforests (Seipp, 1994). Most of the individuals were found on dead trees, in accordance also with Raxworthy \& Vences' (2010) statement that the species appears to live mainly on dead trees within rainforest.

\section{ACKNOWLEDGEMENTS}

We are grateful to The Mohamed bin Zayed Species Conservation Fund for supporting this project (Pro- ject \# 180518200). We thank all the project partners such as Chester Zoo, Rainforest Trust and Mention of Zoology and Animal Biology of University of Antananarivo. Many thanks to the Ministry of Environment for giving research permit for the field work (permit number: $\mathrm{N}^{\circ}$ 021/19/ MEEF/SG/DGF/ DSAP/SCB.Re [Renouvellement de l'autorisation $\mathrm{N}^{\circ} 266 / 17$ du 31/10/2017]). And finally, we thank all the regional/local authorities and people for their precious collaboration during the project implementation.

\section{REFERENCES}

Austin J.J., Arnold E.N. \& Jones C.G., 2004. Reconstructing an island radiation using ancient and recent DNA: the extinct and living day geckos (Phelsuma) of the Mascarene islands. Molecular Phylogenetics and Evolution, 31: 109-122. https://doi.org/10.1016/ j.ympev.2003.07.011

Bower D., Andriantsimanarilafy R.R., Randrianantoandro C., Razafimanahaka H.J., 2014. Habitat use of critically endangered gecko (Phelsuma pronkii) in eastern Madagascar reveals appropriate methods and priorities for research. Unpublished report

Du Puy D. \& Moat J., 1996. A refined classification of the primary vegetation of Madagascar based on the underlying geology: using GIS to map its distribution and assess its conservation status. Biogeographic de Madagascar, 1996: 205-218 
Glaw F. \& Rosler H., 2015. Taxonomic checklist of the day geckos of the genera Phelsuma Gray, 1825 and Rhoptropella Hewitt, 1937 (Squamata: Gekkonidae).

Gray J.E., 1825. A synopsis of the genera of reptiles and Amphibia, with a description of some new species. Annals of Philosophy, 10: 193-217.

Harmon L.J., Melville J., Larson A. \& Losos J.B., 2008. The role of geography and ecological opportunity in the diversification of Day Geckos (Phelsuma). Systematic Biology, 57: 562-573. https://doi.org/10. 1080/10635150802304779

IUCN, 2001. IUCN, Red List Categories and Criteria: Version 3.1. IUCN Species Survival Commission. IUCN, Gland, Switzerland and Cambridge, UK.30 pp.

Madagasikara Voakajy., 2015. Plan d'aménagement global de la nouvelle aire protégée Mangabe-Ranomena-Sahasarotra. Unpbl report.

Preatoni D.G., Tattoni C., Bisi F., Masseroni E., D’Acunto D., Lunardi S., Grimod I., Martinoli A. \& Tosi G., 2012. Open source evaluation of kilometric in- dexes of abundance. Ecological Informatics, 7: 3540. https://doi.org/10.1016/j.ecoinf.2011.07.002

Raxworthy C.J. \& Vences M., 2010. Phelsuma pronki. The IUCN Red List of Threatened Species 2010: e.T178246A7506084. https://dx.doi.org/10.2305/ IUCN.UK.2010

Rocha S., Rosler H., Gehring P. S., Glaw F., Posada D., Harris D.J. \& Vences M., 2010. Phylogenetic systematics of day geckos, genus Phelsuma based on molecular and morphological data (Squamata: Gekkonidae). Zootaxa, 2429: 1-28.

Rocha S., Vences M., Glaw F., Posada D. \& Harris D.J., 2009. Multigene Phylogeny of Malagasy day geckos of the genus Phelsuma. Molecular Phylogenetics and Evolution 52: 530-537.

Seipp R., 1994. Eine neue Art der gattung Phelsuma Gray 1825 aus Zentral-Madagaskar. Senckenbergiana biologica, 74: 193-197.

Uetz P. \& Hošek J., 2014. The Reptile Database, http://www.reptile-database.org.downloaded, 31 July, 2019. 
